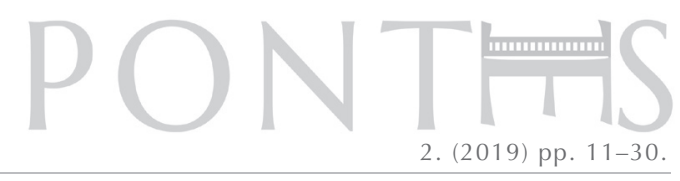

\title{
Csabai Zoltán
}

\section{Babilóniai kölcsönök kezelése szököhónapokban}

\section{Babylonian Loans In Intercalary Months}

The Babylonian calendar is characterized by the use of intercalation. To reconcile the difference between the lunar and solar calendar, intercalary months were inserted. In this brief study a cuneiform economic text from the Early Achaemenid period ( $6^{\text {th }}$ cent. B.C.) is put under scrutiny. A special feature of the tablet, recorded in the reign of Darius I, is the fact that it was written in an intercalary month. In this study I intend to present an analysis on Babylonian interest-bearing loans and intercalary months.

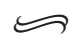

Az ókori Mezopotámiában használt naptárak egyik jellegzetessége a szökőhónapok használata. ${ }^{1}$ A tizenkét hónapos lunáris (29 és 30 napos hónapokat számolva öszszesen 354 nap) ${ }^{2}$ és szoláris év (kb. 365,25 nap) eltérését Mezopotámiában szökö-

1 I gratefully acknowledge the permission of the Trustees of the British Museum to study and publish BM 31230. Szeretném kifejezni köszönetemet Cornelia Wunsch és Enrique Jiménez számára, akik lefotózták részemre a táblát és a fotókat a rendelkezésemre bocsátották. Köszönettel tartozom Földi Zsombornak, aki elkészítette a BM 31230 agyagtábla rajzát, és a tanulmány korábbi változatához számos fontos megjegyzést füzött, amelyek nélkül nem készülhetett volna el. A BM 31230 agyagtábláról készült rajz és a szövegről készített transzliteráció a tanulmány eredeti változatában a Hungarian Assyriological Review folyóirat I. számában jelent meg. A kutatás a TÁMOP-4.2.4.A/2-11-1-2012-0001 Nemzeti Kiválóság Program - Hazai hallgatói, illetve kutatói személyi támogatást biztositó rendszer kidolgozása és müködtetése konvergencia program címü kiemelt projekt keretében zajlott. A projekt az Európai Unió támogatásával, az Európai Szociális Alap társfinanszírozásával valósul meg.

231 napos hónapra nincs példa a szokásos mezopotámiai naptárakban. A mezopotámiai naptárakról és időszámítási módszerekről magyar nyelven lásd Hahn 1988 és Cseke 2008. 
hónapok ${ }^{3}$ közbeiktatásával egyenlítették ki. ${ }^{4}$ A szökőhónapok beillesztése a Kr. e. 1. évezredet megelőzően nem rendszeres, szabályszerü, és elöre kiszámítható. ${ }^{5}$ A késő óperzsa kortól, különösen a Kr. e. 5. század utolsó évtizedeitől a 19 éves ciklus használata vált rendszeressé. ${ }^{6}$ Gazdasági és adminisztrációs forrásokat szökőhónapok vizsgálata esetén ritkán vesznek figyelembe, elsősorban az azonosítás kérdésében nyújthatnak segítséget, vagy a szökőhónapok beillesztésének rendszerességének vizsgálatakor kerülnek szóba. ${ }^{7}$

Az alábbi rövid tanulmányban egy óperzsa agyagtáblát, egy korabeli gazdasági forrást vizsgálunk részletesen. Az I. Dareios uralkodásának idején készült táblának az a sajátossága, hogy szökőhónapban keletkezett, de bátorkodhatunk akár azt is kijelenteni, hogy csupán a szökőhónap volt az ok, ami miatt sor került a megírására.

Az itt tárgyalt újbabilóni ékírásos tábla, a BM 31230 egy egyszerű kötelezvény, amit az ún. u’iltu-k formulája szerint fogalmaztak meg. ${ }^{8}$ A tábla öt mina (kb. $2500 \mathrm{~g}$ ) ezüst (=pénz) kölcsönadásáról szól, amit 20\%-os éves kamatlábbal kellett visszafizetni. A szökőhónap mellett a kamat záradéka miatt fordul a figyelmünk a szöveg felé. Marc Van De Mieroop figyelemreméltó kijelentéseket tett a kutatásban korábban a szökőhónapok és a kamatozó kölcsön kapcsolatára vonatkozóan. Van De Mieroop szerint a szökőhónapok rendszertelen beiktatása a mezopotámiai naptárakba az egyik oka annak, hogy a gazdasági szövegek formuláiban szereplő kamatot nem lehet évi kamatlábként értelmezni, miszerint a ténylegesen fizetendő kamat a kölcsön összegétől és az eltelt időtől függne, hanem egy összegben hozzáadandó kamat(összeg)ként kell értelmeznünk. ${ }^{9}$ Vizsgálata elsősorban a Kr. e. 2. évezredi,

3 A babilóniai szökőhónapoknak általában nincsen külön nevük. Leggyakrabban a 6. (Ulūlu) és 12. (Addaru) hónaphoz kötik őket, és vagy második Ulūlu/Addaru hónapnak, vagy Ulūlu/Addaru szökőhónapnak nevezik őket.

4 Steele 2011. 475-478. A szökőhónapok beiktatásának sémáit tárgyalja a MUL.APIN listában Hunger - Pingree 1999. 75-79; a szökőévek rendjéhez nyújt újabb szempontokat Ratzon 2016.

5 Hunger 1977. Az újbabilóni és óperzsa kor szökőhónapjaihoz és szökőéveihez lásd Steele 2007. 137-140.

6 Az óperzsa és hellenisztikus 19 éves ciklusban az 1., 3., 6., 9., 12., 14., és 17. év mindegyikében volt egy szökőhónap. A ciklus 12. évét leszámítva, amikor Ulūlu szökőhónap (azaz második Ulūlu - hatodik - hónap) volt, mindegyik szökőévben Addaru szökőhónapot (azaz második Addaru - tizenkettedik - hónapot) alkalmaztak. Az első három ciklusban az Ulūlu szökőhónap beiktatása bizonytalan, de a Kr. e. 419/418-401/400 ciklustól kezdve a szökőévek rendje szabályosan megfigyelhető. Részletesen lásd Ossendrijver 2018. 139-140. és 147-149.

7 A szökőhónapok rendszere és a gazdasági, adminisztratív források közötti kapcsolatokat legutóbb vizsgálta Stratford 2015. (óasszír forrásanyag segítségével).

8 Az újbabilóni kötelezvény, az u’iltu felépítéséhez, értelmezéséhez lásd Petschow 1956; továbbá Oelsner 2001. 289-305.; Jursa 2002. 197-203.; Wunsch 2002. 224-230.; Oelsner - Wells - Wunsch 2003. 949-961.

9 Van De Mieroop 1995. 360. és 2005. 29. 
óbabilóni gazdasági forrásokon alapult, mégis érvényesnek tartja ezt a szabályszerüséget Babilónia későbbi korszakaira is. A kamatozó kölcsönök ilyen értelmezése Van De Mieroop véleménye szerint megfelelő megoldást kínál a váratlan szökőhónapok okozta anomáliák kezelésére. Indoklása azon nyugszik, hogy ha kamatlábként értelmeznénk a szövegben szereplő arányszámokat, akkor egy szökőhónap beiktatásával teljesen felborulna a kamat addigi fizetése, és újra kellene kalkulálni az évből addig eltelt hónapok fizetését, és a későbbi hónapok kamatát. Véleménye szerint ennek a problémának a kikerülése miatt kellene a kölcsönökben szereplö kamatot egy öszszegben a tőkéhez hozzáadandó kamatként, és nem kamatlábként értelmezni.

Javaslatával ellentétes véleményt fogalmazott meg Vargyas Péter, aki a kutatási eredményeinél a Kr. e. 1. évezredi babilóni források vizsgálatára támaszkodott. ${ }^{10}$ Vargyas véleménye szerint a babilóniak részletesen kifinomult formulát használtak a kamat kifejezésére, és a fejlett matematikai ismereteik miatt sem okozott gondot számukra kiszámolni a fizetendő kamatot egy szökőhónap beiktatása esetén. Javaslatát azonban Van De Mieroop elutasította, és bár az óbabilóni forrásokon nyugszik a kutatása, újból hangsúlyozta, hogy annak eredménye Babilónia minden korszakára érvényes. ${ }^{11}$ A kérdés eldöntése érdekében vizsgálat alá vesszük a kamatozó kölcsönöket, remélve, hogy segítséget nyújt a vita lezárásában.

Tizenhat publikált kölcsön ismert a Kr. e. 1. évezredi Babilóniából, ami kamattal kapcsolatos és valamelyik szökőhónapban született. ${ }^{12}$ Mivel minden gazdasági, adminisztratív forrást pontos dátummal láttak el, ezért tudjuk, hogy a szövegek Kr. e. 653-tól Kr. e. 269-ig keletkeztek, de a többségüket Kr. e. 621 és Kr. e. 499 között írták. Addaru szökőhónapból több szerződés maradt fenn, mint Ulūlu szökőhónapból, de ez nem egyedülálló tendencia, mert több Addaru szökőhónapot ismerünk, mint Ulūlu szökőhónapot, és az is megfigyelhető, hogy több kölcsönszerződés köttetett a babilóniai év második felében, mint az elsőben. ${ }^{13}$

Az iratok között négy kézizáloggal (Zinsantichrese) kapcsolatos kölcsön szerepel. ${ }^{14}$ Ezek közül kettő klasszikus, tisztán kézizálog, egyikben egy szolgát, ${ }^{15}$ másikban egy házat ajánlanak fel ${ }^{16}$ a kamat fizetése helyett. Utóbbi esetben rendkívül nagy összegű a kölcsön, 600 sékel (kb. 5 kg ezüst). A harmadik példában a hitelezett ösz-

10 Vargyas 2000. 1102.

11 Van De Mieroop 2005. 361. 41. j.

12 Az újbabilóni kor kamatlábaihoz és értelmezéséhez lásd Csabai 2006. és 2018b.

13 Csabai 2008. 205-207. Ezen a helyen az év első és második fele alatt nem a kalendáriumi, hanem az aratástól aratásig tartó gazdasági évet értem.

14 Kézizálog szerződés esetében az adós a kamat fizetése, felszámítása helyett egy másik bevételi forrást ajánl fel a hitelezőnek. Ilyen kamatot helyettesítő juttatás volt jellemzően a házak bérbeadásából származó jövedelem átruházása a hitelező javára.

15 TMH 2/3 115 (Kr. e. 549).

16 TCL 1221 (Kr. e. 605). 
szeg felét fedezi a hitelező javára átruházott ház bérbeadásából származó jövedelem. A kézizálogból származó jövedelem segítségével csak a kölcsön másik fele után kellett kamatot fizetni. ${ }^{17}$ A negyedik esetben egy két hónapos késleltetett kamatozású hitelről van szó, amelynél az adós a ruha ellátmányát ajánlja fel (ebből a szempontból ez további példa nélküli eset) arra az időre, amikortól kamatot kell fizetni. ${ }^{18}$

Egy hubuttu kölcsön ${ }^{19}$ is van közöttük, igaz ez nem ezüstről, hanem árpáról szól. ${ }^{20}$ Tizenhárom kamatozó kölcsön van, egynél kitörött a kamatlábról szóló szakasz, ${ }^{21}$ egy esetben pedig bizonytalan. ${ }^{22}$ Ebben a szűk forrásanyagban az alábbi éves kamatlábak fordulnak elő: $8,33 \%,{ }^{23} 12,5 \%,{ }^{24} 16,66 \%{ }^{25}$ és $20 \%{ }^{26}$.

A kamat felszámításának, fizetésének kezdetére vonatkozóan szinte minden típus megtalálható ebben a szűk keresztmetszetben is. Három késleltetett kamatozású szerződés található köztük, amelyek közül az egyikről ${ }^{27}$ már volt szó. A másik kettő a kölcsön megírása utáni hónap első napjától kezd kamatozni. ${ }^{28}$ Ez feltételezhetően a kamat fizetésének ütemezése miatt volt így. A következő kilenc szerződés mindegyike olyan kölcsön, amelynél a kamat fizetésének kezdete még a szökőhónapban megkezdődött. Van legalább egy visszadátumozott hitelszerződés, amelynél a kamat fizetésének a kezdete a szerződéskötés hónapjának, azaz Addaru szökőhónap első napja. ${ }^{29}$ Kettő esetben konkrétan kifejezi a szerződés, hogy a kamatot a szerződéskö-

17 Ellis 1984. no. 1. (Kr. e. 653) A kölcsön összege tíz mina (600 sékel = kb. 5 kg) ezüst volt. Öt mina ezüstért minánként öt sékel ezüst kamatot kellett fizetni (=8,3\% kamat évente). A másik öt mina ezüst kamatköltségéért pedig egy ház bérleti jövedelmét ajánlották fel kézizálogként (azaz a ház éves bérletét 25 sékel értékben határozták meg). Újbabilóni házbérletek példái olvashatók: Csabai 2003.

18 Jursa 1998. no. 16. (Kr. e. 269). Egy viszonylag kicsi összeg ellentételezéseként a hitelező három zálogot is kért az adóstól (a kézizálog mellett az adós felesége és fia is szerepelt a kölcsön biztosítékaként).

19 A h̆ubuttu (valamint a h̆ubuttūtu és ḩubuttātu) kölcsönök egészen pontos értelmezése vitatott. Ehhez lásd Skaist 1994. 52-56.; Westbrook 2003b. 403; Slanski 2003. 510; az újbabilóni forrásanyagot tárgyalta Petschow 1956. 15 31. j.; Shiff 1988; Oelsner - Wells - Wunsch 2003. 950; a Sîn-uballiṭ archívum vonatkozó szövegeiről röviden Cseke 2014. 573-574. A kérdésről magyarul lásd Csabai 2015.

20 VS 335 (Kr. e. 562): 1.1.0.0. (216 liter) árpa, Ālū Bānītūyában.

21 Kessler 1991. no. 88: 1' (Kr. e. 603).

22 YOS 19 26: 5 (Kr.e. 546).

23 Ellis 1984. no. 1: 3-4 (Kr. e. 653) és BE 8/1 157: 4-5. (Kr. e. 621).

24 OECT 12 A 91: 4-5 (Kr. e. 574).

25 Hunger 1970. no. 17 III: 26-35. (Kr. e. 598).

26 Hunger 1970. no. 17 II: 6-20. (Kr. e. 600); Nbn 438 (Kr. e. 546); Nbn 678 (Kr. e. 543); Cyr 219 (Kr. e. 532); BM 31230 (Kr. e. 516); Dar 556 (Kr. e. 499); Jursa 1998 no. 16 (Kr. e. 269).

27 Jursa 1998. no. 16.

28 Dar 556 és részben az itt tárgyalt BM 31230.

29 Nbn 678 kölcsönt Addaru szökőhónap 16. napján írták, a kamatot azonban Addaru szökőhónap 1. napjától számították. 
tés napjától kell fizetni. ${ }^{30}$ Hét kölcsön esetében pedig a legegyszerübb formában írják elö a kamat fizetését, a szerződéskötés napjától kezdve. ${ }^{31}$

A szökőhónapokból fennmaradt kamatozó kölcsönök esetében nem találkozunk olyan záradékkal sem a kamat formulájánál, sem a források többi kitételét tekintve, ami miatt azt kellene feltételeznünk, hogy a szökőhónapokban megkötött kamatozó kölcsönök rendkívüli jogi, adminisztrációs helyzetet teremtettek a szerződő felek számára. Úgy tünik, hogy a használt terminusok, feltételek, záradékok megegyeznek a normál és a szökőhónapokban kötött kötelezvények esetében az újbabilóni és óperzsa korban. Mégis az a tény, hogy a tizennyolc kölcsönből tizenegy esetben a kamatot már a szökőhónaptól felszámították, arra utal, hogy a szökőhónap nem számított ebből a szempontból különlegesnek, ennek idejére is kellett kamatot fizetni.

\section{BM 31230}

A következő forrás, amit közelebbről vizsgálunk, segíthet a kérdés eldöntésében. A babilóni hitelezés szokásából a kutatás számára ismert korábbi szerződések megújítása, vagy újrafogalmazása. A BM 31230 kölcsön esetében is így van (legalábbis ez lehet a kiindulópontunk), és olyan kivételes helyzetben vagyunk, hogy a korábbi dokumentum is a rendelkezésünkre áll (Dar 170). Éppen ezért lehetőség nyílik a két dokumentum összehasonlító vizsgálatára. Általában a megújítás az elmaradt fizetésre, a fizetési feltételek megváltoztatására, vagy az eredetitől eltérő összegről szóló szerződés megkötésére irányult. Úgy tűnik ebben az esetben ez nem feltétlenül igazolható.

A BM 31230 ékírásos szöveg az újbabilóni kor legnagyobb és leghíresebb archívumának, az Egibi archívumnak a része. ${ }^{32} \mathrm{Az}$ Egibi archívumon belül a kölcsön a negyedik generáció legfontosabb, aktív személyéhez - akihez a generáció dokumentumainak többségét is kötjük - Marduk-nāșir-aplihoz tartozik. ${ }^{33} \mathrm{Ez}$ a két ékírásos szöveg nem szerepelt az archívum kiadott szövegei között. A Dar 170 kópiája és transzliterációja már publikált formában elérhető, ${ }^{34}$ ezért itt csak a fordítást közöljük, és ugyanígy járunk el a BM 31230 tábla esetében is. Mindkét esetben kommentár kíséretében mutatjuk be a szöveget.

30 Hunger 1970. no. 17. II: 6-20 és III: 26-35.

31 Pl. Nbn 438: 5-7 sorok: ša arḩi ina muhhi 1 manê 1 šiqil kaspi ina muḩhīšu irabbi 'havonta 1 minánként 1 sékel ezüsttel növekszik a terhére'.

32 Az Egibiek általános bemutatására alkalmas Wunsch 1999a; 1999b; 2007. Az archívum egyes területeinek részletes elemzéséhez lásd Wunsch 2000. és Abraham 2004.

33 Az Egibi forrásokon belül a Marduk-nāșir-apli archívumot részletesen bemutatta Abraham 2004.

34 Joannès 2000/2002. 


\section{Dar 170}

ezüst kötelezvény

Babilón, I. Dareios 5-VI-16 (Kr. e. 517. szeptember)

\section{Fordítás}

${ }^{1}$ Öt mina kereskedelemben ${ }^{35}$ használt ginnû-ezüst, amiben $1 / 8$ (az ötvözetet), ${ }^{3}$ amivel Marduk-nāṣir-aplinak, Itti-Marduk-balāṭu fiának, Egibi leszármazottjának Nabû-apla-iddin, ${ }^{5}$ Nabû-ēṭir fia, Isinnāya leszármazottja tartozik.

Havonta, minánként egy sékel ezüsttel növekszik a terhére (= 20\% kamat $\left.{ }^{36}\right)$. ${ }^{7} \mathrm{El}-$ tekintve egy korábbi kölcsöntől [aminél?] Nabû-apla-iddin jelen volt(?).

${ }^{9}$ Tanúk: Arrabu, Šangû-[...] leszármazottja; [...], Atû leszármazottja; ${ }^{11}[\ldots]$ Marduk-nāṣir-apli [fia], [... leszármazottja]; Marduk-balāssu-iqbi, ${ }^{13}$ [Bān]īya [fia], Nabaya leszármazottja; [Nergal-ušal]lim?, Mušēzib-Marduk fia, ${ }^{15}$ Nappāh̆u (=Kovács) leszármazottja; Nabû-apla-iddin, Iddin-Nabû fia, Dābibī leszármazottja.

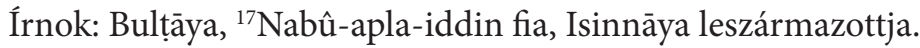

Babilón, Ulūlu 16. ${ }^{19}$ (I.) Dareios, Babilón és az országok királyának ötödik évében.

\section{Kommentár és jegyzetek}

(1-2) A kaspu ša ginnu (=ginnû-ezüst) kifejezést Vargyas Péter Dareios ezüst pénzérméjeként, az ezüst siglos-ként azonosította. ${ }^{37}$ Azonban a korai mezopotámiai pénztörténet kiemelkedő ismerője, Marvin Powell véleményén túl, ${ }^{38}$ ez az elképzelés még nem nyert támogatást az újbabilóni gazdaságtörténet kutatóinak többsége között. ${ }^{39}$ Ehelyett Michael Jursa magyarázatát követik jelenleg. ${ }^{40} \mathrm{~A}$ kaspu ša ginnu $\check{s} a$ nadāni u mahāri 'kereskedelemben használt ginnû-ezüst' kifejezés fordítása és jelentése vitán felül áll. ${ }^{41}$

35 Szó szerint: „ami az adás és vétel (ezüstje)”.

361 mina 60 sékel ezüst, havonta 1 sékelnyi kamat az évente 12 sékel, ami a minához viszonyítva 20\%-nyi éves kamatlábnak felel meg.

37 Vargyas 1999; Vargyas 2001. 24-34., magyarul lásd Vargyas 2010. 95-111.

38 Powell 1999, 21-23.

39 Az óperzsa siglos-okról, a korábbi szakirodalom kritikai értelmezésével együtt lásd Corfù 2010.

40 Véleménye szerint a ginnû olyan ezüst volt, ami magán viselt valamilyen közelebbröl nem meghatározható jelzést talán a minőségére (ami elmarad a siglos-érmékétől), vagy a formájára tekintettel. Ezek az azonosító jegyek nem Dareios siglosaira utaltak, már Dareios uralkodása előtt megjelentek, és csak bizonyos tranzakciókban tünnek fel, ehhez ld. Jursa et al. 2010. 480-485.

41 Vargyas 2001. 21-24 és Jursa et al. 2010. 488-489., magyarul lásd Vargyas 2010. 91-95. 
(3-5) A hitelező, Marduk-nāṣir-apli/Itti-Marduk-balāṭu//Egibi Az Egibi család negyedik generációjának legfontosabb szereplője. ${ }^{42} \mathrm{Az}$ adós, Nabû-apla-iddin/ Nabû-ētir//Isinnāya más forrásból nem ismert a Marduk-nāṣir-apli archívum publikált szövegei között.

(6-7) Ez az egyik leggyakoribb kamatra vonatkozó záradék az újbabilóni iratok között, havonta történő kamatszámítással kifejezett évi 20\%-os kamatot jelent.

Dar 170-ben hat tanú rekonstruálható. Nergal-ušallim/Mušēzib-Marduk// Nappāhuu az egyetlen, aki mindkét itt tárgyalt forrásban (Dar 170 és BM 31230) tanúként szerepel. ${ }^{43}$

Bulțāya/Nabû-apla-iddin//Isinnāya volt mindkét szerződés írnoka. Feltételezhető, hogy az írnok az adós fia volt. Az újbabilóni korból több olyan kölcsönszerződést is ismerünk, amelynél az írnok az adós (kötelezett) családjához kötődik, ${ }^{44}$ néhány kivételes esetben az adós volt az írnok is. ${ }^{45}$

\author{
BM $31230(=\text { Bertin 2067) })^{46}$ \\ ezüst kötelezvény \\ Babilón, (I.) Dareios 5-XII2-4 (Kr. e. 516. március)
}

\title{
Fordítás
}

${ }^{1}$ Öt mina kereskedelemben használt ginnû-ezüst, amivel Marduk-nāṣir-aplinak, Itti-Marduk-balāṭu fiának, ${ }^{3}$ Egibi leszármazottjának Nabû-apla-iddin, Nabû-ēṭir fia, Isinnāya leszármazottja tartozik.

42 Abraham 2004. 13-16.

43 Nergal-ušallim(=Šullumu)/Mušězib-Marduk//Nappāhuu legalább hatszor megjelenik a Marduk-nāṣir-apli archívum szövegeiben tanúként: Abraham 2004. no. 85. (BM 41449); no. 97. (= Dar 182); no. 100. (= Dar 213); no. 102. (= Dar 268); no. 110. (= Dar 338); no. 112. (= Dar 345). Külön érdekesség, hogy azon szövegek közül, amelyekben tanúként szerepelt, négy iratot is Dareios 5. évében írtak: a tanulmányban tárgyalandó Dar 170 és BM 31230, valamint Abraham 2004. no. 85., és no. 97. dokumentumokat). Ezek mindegyikében Nergal-ušallimként nevezték meg. A másik négy szövegben, I. Dareios 6. (no. 100.), 10. (no. 102.), 12. (no. 110.), és 13. (no. 112.) éveiböl Šullumuként nevezik meg. Éppen ezért azt feltételezem, hogy az Abraham 2004. no. 85. szöveget a kitörött dátuma ellenére (a keltezés kérdéséhez lásd Abraham 2004. 364), szintén I. Dareios 5. évében írták.

44 Például Nbk 68: az adós Nabû-gāmil/Rih̄etu//Sîn-nāṣir, az írnok Nabû-zēr-ibni/Rihēetu//Sînnāșir. Nbk 281: az adós Nabû-aḩ̧̄ē-iddin/Nabû-kēšir//Naggāru, az írnok Bēl-zēr-ibni/Nabûkēšir//Naggāru.

45 VS 4 10: Bēl-uballiț/Mīnu-ana-Bēl-dannu//Nūr-Šamaš egyszerre az adós és az írnok. Dillard 1975. FLP 1522: az adós és az írnok is Nabû-êțir-napšāti/Nabû-šum-iškun.

46 A tábláról először George Bertin készített rajzot 19. század végén, azonban munkája kéziratban maradt. 
${ }^{5}$ Addaru hónap és! Nisannu hónap 1. napjától havonta minánként egy sékel ezüsttel ${ }^{7}$ növekszik a terhére. ${ }^{47}$ Eltekintve egy másik kölcsöntől, amivel Nabû-apla-iddin és Iqūpu (tartozik).

${ }^{9}$ Tanúk: Nergal-ēṭir, Nabû-aḩhē-iddin fia, Egibi leszármazottja; ${ }^{11}$ Nergal-ušallim, Mušēzib-Marduk fia, Nappāhu leszármazottja.

Írnok: Bulțāya, Nabû-apla-iddin fia, ${ }^{13}$ Isinnāya leszármazottja.

Babilón, Addaru szökőhónap 4. (I.) Dareios, ${ }^{15}$ Babilón és az országok királyának 5. évében.

\section{Kommentár és jegyzetek}

(1-2) Mivel a ma.na jelek előtt nagyon kevés hely van a táblán, ezért azt feltételezzük hogy csak egy ékjel, legnagyobb valószínűséggel egy egész szám szerepel ott. A Dar 170 szerződés megírása óta kevesebb mint hét hónap telt el, ezért nem gondolom, hogy az összeg kevesebb lett az idő során. Azonban egy minával sem lehetne több, mert figyelembe véve a 20\%-os kamatlábat, ennyivel nem nőhetett a tartozás (az eltelt hónapokat tekintve 30, vagy 36 sékellel növekedhetett az 5 mina töketartozás, de ennek a táblára való írása több jelet, több jelnek való helyet igényelne a táblán). A fentiekből következően a kölcsön összegét a Dar 170 szerződésből állítottam helyre.

A második szerződés (BM 31230) egy megújított megállapodás, a kölcsönt hét hónappal korábban már átadták, vagy rögzítették. Úgy gondolom ez az oka, hogy az írnok elhagyta az ezüst pontos finomságának megnevezését (875\%o: lásd Dar 170, 1. sor: kaspu ša ina 1 šiqil bitqa - ezüst amiban 1/8 (az ötvözetet). Mivel a ginnû-ezüst jellemző finomsága amúgy is $875 \%$ o, ${ }^{48}$ elég a megújított szerződésben az ezüst legfontosabb tulajdonságait megnevezni.

(3-4) A Dar 170 és BM 31230 iratokat leszámítva az adósként szereplő Nabû-apla-iddin/Nabû-êtị//Isinnāyának nincsen semmilyen ismert kapcsolata a Marduk-nāșir-apli archívummal. ${ }^{49}$

(5-7) Ez egy bővített, részletezett változata a kamat babilóni meghatározásának, és két elemet is hordoz magában. Az első kitétel a záradékban meghatározza a pontos napot, amikortól a kamatot felszámítják a tartozás után. Az ismert, kamatozó kölcsönök vizsgálatából megállapítható, hogy a kamat számításának a kezdete gyakran nem esik egybe a dokumentum dátumával. A záradék különböző változataiból öszszességében megállapítható, hogy a kamat felszámítása kezdődhet 1) a kölcsönszer-

\footnotetext{
47 Amennyiben tizenkét hónapra számolják fel a kamatot, akkor ez évente 20\%, ha a szökőhónapra is kell kamatot számolni, akkor ez évi 21,66\% lenne.

48 Vargyas 2001. 24.; Jursa et al. 2010. 481.

49 Abraham 2004.
} 
ződés dátumával megegyező napon; 2) a kölcsönszerződés dátuma utáni első naptól; 3) a kölcsönszerződés dátuma után következő valamelyik hónap első napjától; ${ }^{50} 4$ ) vagy, néhány esetben kamatot kellett fizetni a szerződés dátuma előtt lévő napokra, hónapokra, tehát a kamat fizetését a szerződés előtti periódusra is érvényesítették - mondhatnánk: visszadátumozva. ${ }^{51}$ Mindezek mellett azonban, a záradéknak az a formája, amit a BM 31230 5. sorában olvasunk, miszerint kettő hónapot is megnevez, amelyik hónap 1. napjától a kamatot felszámítják, korábban nem fordult elő. A Kr.e. 1. évezredi babilóniai gazdasági szövegkorpuszban egészen eddig egyedülállónak számít. A kamatra vonatkozó záradék 6-7. sorokban olvasható második eleme a kamat szokványos kifejezése, és egyben meg is egyezik a korábbi Dar 170 kölcsön 5-7. sorában olvashatókkal.

(7-8) Mivel a Dar 170 szerződés adósa egyedül Nabû-apla-iddin/Nabû-ētị// Isinnāya volt, és az az adósság, amit a BM 31230 korábbi hitelre vonatkozó elat-záradékában említenek a dokumentum 7-8. soraiban két adósra vonatkozik, Nabû-apla-iddinre és Iqūpura, ezért ezek a sorok nem vonatkozhatnak a Dar 170 szerződésre, hanem egy másikra. Valószínüleg ugyanarra a kölcsönre, amit a Dar 170 7-8. soraiban is említenek.

(9-11) A két tanú közül Nergal-ušallim/Mušēzib-Marduk//Nappāḩu az elsö dokumentumnál is jelen volt tanúként.

A BM 31230 a majdnem hét hónappal korábban készült eredeti Dar 170 megújítása. Nincsen változás a szerződő felekben, nem került bele új záradék, és a záradékok sorrendje is ugyanaz maradt. A két dokumentum az alábbi pontokban különbözik egymástól: a második szöveg az ezüst minőségét mutató jelzőket egy rövidebb változatban írja le, emellett a kamatra vonatkozó záradék több részletet tartalmaz, végül pedig az ún. elat-záradékban egy második adóst is megnevez. Ezektől az apró eltérésektől eltekintve a megállapodás alapvetően ugyanaz maradt. A hitelező és adós személye másodszor is megegyezik, a kölcsön összege valószínűleg ugyanaz maradt, és mindkét szöveg megemlít egy másik kötelezvényt. Ezek után adódik a kérdés: vajon miért írták újra az eredeti szerződést? Feltételezhető, hogy a megoldás azokban a kisebb változásokban rejlik, amelyeket fentebb megneveztünk.

$\mathrm{Az}$ ezüst minőségének rövidebb leírása ugyanazt az ezüst típust jelöli, ezért ezt elvethetjük. Az elat-záradékban újonnan szereplő személy pedig sem az aktuális sem a korábbi (Dar 170) kölcsönnek nem aktív szereplője. Ebből következően egyedül a kamat záradékának kiegészítése lehet az, ami miatt a szöveg leírásra kerülhetett. Az ötödik sorban azt olvashatjuk, hogy Addaru és Nisannu hónap elsejétől kamatozik

50 Késleltetett kamatozású kölcsönnél a kamat felszámítása az eredeti kölcsön megírása utáni hónapokban kezdődhetett, de sosem haladta meg az egy évet. Ehhez lásd Csabai 2018a. 19.

51 Csabai 2018a. 
20\%-ot a kölcsön. Ez a teljes Kr. e. 1. évezredi babilóniai forráscsoportot, újbabilóni, óperzsa, szeleukida forrásokat áttekintve egyedülálló eset. Rendszerint a záradékokban valamely hónap első napjától adják meg a kamatozás periódusát, a BM 31230 táblán kívül kettő hónapot egyszer sem neveznek meg. Ráadásul ez a két hónap a babilóni év utolsó és első hónapja, tehát két egymást követő hónap. Ha azonban kettő, egymást követő hónapról van szó, akkor jogosan tesszük fel kérdést, hogy a záradékban miért nevezték meg mind a kettőt, amikor azt látjuk, hogy mindkét esetben ugyanúgy $20 \%$ a kamat. Miért írja le mindkét hónapot, ha a záradék szerint már Addaru hónap 1. napjától kamatozik, akkor ugyanez érvényes a következő hónapra, Nisannura is. Esetleg más kamatláb vonatkozhat két egymást követő hónapban? Ezt kizárhatjuk, hiszen csupán egy kamatláb szerepel benne és az év korábbi szakaszából származó Dar 170 forrásban is ezt a kamatot határozták meg. Mindkét hónapban kamatozik a kölcsön, és mindkét hónapra ugyanaz a kamatláb szerepel. Így tehát elég lett volna csak az egyik hónapot megnevezni - azonban itt most nem ezt olvashatjuk. A két hónap megnevezése ezért továbbra is tisztázatlan.

A BM 31230 dátumának vizsgálata segíthet megoldani a kérdést. A táblát Addaru szökőhónapban írták. A Kr.e. 1. évezredből származó források tanúsítják, hogy Addaru szökőhónap nem csak a normál Addaru hónap után, hanem előtte is lehetett. ${ }^{52} \mathrm{Ez}$ azonban úgy tünik, hogy csak az újbabilóni korszakban fordult elő. Ossendrijver szerint normál Addaru hónapot megelőző Addaru szökőhónap az óperzsa kortól nem fordul elő. ${ }^{53}$ Ezért el kell vetni annak a lehetőségét, hogy az I. Dareios korából származó BM 31230 táblán megadott Addaru szökőhónap a normál Addaru hónapot előzte volna meg.

A kölcsönt majdnem hét hónap után megújították ugyanazon feltételeket és záradékok kíséretében, beleértve a 20\%-os kamatot is. A kölcsön tehát látszatra ugyanaz, ezért a megújításának motivációját egyértelműen az előre nem ismert szökőhónap központi beiktatásában kell keresnünk.

A kamatot azonban nem a BM 31230 szerződés dátumától számították, és nem is a szökőhónap 1. napjától - visszadátumozva -, ahogyan bármelyik másik napjától sem, hanem az előző Addaru és a szerződést követő hónap 1. napjától. A kamat ugyanúgy $20 \%$, mint az eredeti kölcsönben, ezért nem marad más lehetőség az ér-

52 Lásd San Nicolò 1933. Vonatkozó forrásait kiegészítette azóta Kleber 2008. 267. 752. j.; de legújabbként vö. Ossendrijver 2018.

53 Ahogyan arra Ossendrijver 2018. 138-139. rámutatott. Azonban Ossendrijver nagyon alapos tanulmánya I. Dareiosnak az utolsó, és az őt követő uralkodóknak az éveivel foglalkozik. Javaslata szerint a 19 éves ciklus Xerxés 10. uralkodási évétől figyelhető meg, de az első ciklusokban az Ulūlu szökőhónap használata nem volt szabályos (az azon belüli éveket tekintve - lásd 6. jegyzet). Britton eredményei (2002. 30-36) alapán tudjuk, hogy a 19 éves ciklus nem szabályos változata már Kyros és Kambysés uralkodása alatt megfigyelhetö, ezért Ossendrijver és Britton kutatásai alapján kimondható, hogy a BM 31230-ban szereplő Addaru szökőhónapra csak a szokásos Addaru hónap után kerülhetett sor. 
telmezésre, mint hogy a két megnevezett hónap között lévő Addaru szökőhónapban az adósnak nem kellett kamatot fizetni! ${ }^{54}$

Mindezt azért mondhatjuk, mert ha kamatot kellene fizetni Addaru szökőhónapban, akkor (a) elég lett volna a szerződéskötés napját megelöző normál Addarut megnevezni, de ebben az esetben a következő Nisannu hónap megnevezése értelmetlen, (b) vagy a kamatot elegendő lett volna Addaru szökőhónap 1. napjától fizetni, vagy (c) az is megfelelő lett volna, ha a kamatot a szerződés megkötésének dátumától kellett volna számítani a folytonosság kedvéért, de mindkét utóbbi eset is arra világít rá, hogy két hónap megnevezése felesleges lett volna.

Következésképpen az egyetlen megoldás az itt vizsgált szövegben olvasható szokatlan anomáliára, hogy a szökőhónapban nem kellett kamatot fizetni. Azonban továbbra is magyarázatra szorul, hogy ha a szökőhónapban nem kell fizetnie az adósnak, akkor miért nem egyszerüen azt írták, hogy a következö, Nisannu hónap 1. napjától fognak kamatot elszámolni. Véleményem szerint azonban nem véletlen mindkét hónap megnevezése, azért, mert ez nem egy megújított szerződés, hanem szerződésmódosítás! Mert megújítás esetén az eredeti kölcsön feltételei elévülnek, és az újak lépnek életbe, de a szerződéskötés napjáig a régi feltételek az irányadóak.

A Dar 170-ben havonta 20\%-os kamatot állapítottak meg az öt mina ezüst tökére, amit minden elkezdett hónapra felszámítottak. Ez a szerződés a szökőhónap negyedik napján keletkezett, azaz erre a hónapra is vonatkozott már a Dar 170-ben meghatározott 20\%-os kamat fizetése. Ezért nem köthettek egy olyan szerződést, hogy majd Nisannu hónap elsejétől kamatozik a kölcsön, mert az adós kötelessége a szökőhónapban fizetendő kamatra attól még nem évülne el. Ezért szükségesnek vélték, hogy a szerződésben szerepeljen az, hogy Addaru és Nisannu hónap elsejétől kell kamatot fizetni. Bármelyik hónap elhagyása azzal járt volna, hogy a szökőhónapra is kamatot kellett volna fizetnie Nabû-apla-iddinnek.

A BM 31230 szerződés még egy fontos elemére szeretném felhívni a figyelmet. A szerződést a hónap negyedik napján kötötték, a hónapnak közvetlenül az elején. Ez arra utalhat, hogy a kamat a kölcsön tőkéjére a hónap elején terhelödik, és a szerződést még azelött kellett megkötni, hogy ezt a kamatot hozzáadják az adóssághoz. $\mathrm{Az}$ adós pedig éppen ennek a kamatnak felszámítását, fizetését kívánta elkerülni. Itt szeretnék még egy témára kitérni, az adós motivációjának gazdasági hátterére, ami az eredeti megállapodás módosításához vezetett. A kölcsönben szereplö összeg (300 sékel $=\mathrm{kb}$. 2,5 kg ezüst) babilóni viszonylatban hatalmas tételnek számított, I. Dareios korában - munkatípustól függően - 5-10 ember egy évnyi fizetésével volt egyenlő. ${ }^{55}$

$54 \mathrm{Ha}$ az ötödik sort szó szerint fordítanánk 'Addaru hónap 1. napjától Nisannuval', akkor is ugyanerre az eredményre jutnánk.

55 Az újbabilóni és óperzsa bérekkel kapcsolatban lásd Jursa et al. 2010. 669-728.; legújabban Jursa 2015, további irodalmi hivatkozásokkal. A babilóniai bérek értékének elhelyezése a megélhetési 
A kölcsön havi kamata is nagy összegnek tekinthetö, havi öt sékel ezüst (kb. 41,5 g ezüst). Ez volt tehát az indokolt gazdasági motiváció, ami miatt az új szerződés megszületett. Feltételezhető, hogy amikor az adós (és az írnok, aki az adós fia) szembesült azzal, hogy szökőhónap következik az évben, megpróbálták módosítani a korábbi szerződést. Úgy véljük, hogy ez csak a hitelező hozzájárulásával, kölcsönös megállapodás segítségével jöhetett létre, aminek az eredményét látjuk a BM 31230 táblán.

Az állami adminisztráció által beiktatott szökőhónapokra is felszámított kamat fizetésének elkerülésére való törekvés, amit jól tükröz számunkra a BM 31230, azonban nem egyedi példája a forrásainknak. Amennyiben jól értelmezem az események láncolatát, legalább még egy esetet ide sorolhatunk. Ismerünk egy példát II. Nabû-kudurrī-ușur uralkodásának idejéből, habár a kérdéses dokumentumot nem szökőhónapban írták. Bernd Funck publikált és kommentált több kora újbabilóni kötelezvényt, amelyek közül három érdekes számunkra ebben a kérdéskörben. ${ }^{56}$ A három tábla összefügg egymással, mindegyik ugyanannak a kölcsönügyletnek bizonyítékaként szolgál (fordításukat lásd a mellékletben). II. Nabû-kudurrī-uṣur harmadik, negyedik és hetedik évéből származnak (Kr. e. 602/601, 601/600, 598/597-es évek). A szövegek egy kölcsönről számolnak be, amire 20\% kamatot kell fizetni. ${ }^{57}$ A fent megadott évek közül II. Nabû-kudurrī-uṣur 7. évéből tudjuk, hogy beiktattak az év felénél egy Ulūlu szökőhónapot.

Az első szöveget ${ }^{58}$ Addaru hónap (XII. hónap) 15-én írták 15 sékel ezüstről, ami után 20\% kamatot számítottak fel ugyanazon hónap 20. napjával kezdőden. ${ }^{59}$ A második iratot (Nbk 39) egy évvel később, ugyanúgy Addaru hónap egyik napján írták (a napra vonatkozó ékjel kitörött), és 20\% kamatot kellett utána fizetni szintén Addaru hónap egyik napjától (a pontos napra vontakozó ékjel itt is kitörött). ${ }^{60}$ A kölcsönre vonatkozó harmadik dokumentum II. Nabû-kudurrī-ușur 7. évéböl származik. Az új megállapodás ${ }^{61}$ feltételei változatlanok voltak, az összeg továbbra is 15 sékel volt, amire $20 \%$ kamatot róttak ki. Azonban, az eddigiektől eltérően

költségek tekintetében egy egészen új témája a babilóni gazdaság kutatásának, ehhez lásd Pirngruber 2016.

56 Nbk 34. (= Liv 5.); Nbk 39. és Nbk 60. (= Liv 141.). Lásd Funck 1982. 51-52. Fordításukat lásd a mellékletben.

57 A hitelező Kudurru/Iqīšāya volt, az adós Mukīn-zēri/Pir’u az Nbk 34 forrásban. A Nbk 39 szövegben két adós volt, Kīnāya(=Mukīn-zēri)/Pir’u és felesége Bu’iti, akik közül az utóbbi már egyedül szerepel a harmadik dokumentumban (Nbk 60.). Funck (1982. 52.) szerint az eredeti kölcsön kétszeri megújításának oka az adós személyében történő változása rögzítése volt.

58 Nbk 34.

59 Nbk 34: 3-6. és 13. sorok.

60 A pontos nap ékjele mind a kamat záradékában, mind a dátumban kitörött a tábláról, de a hónap mindkét esetben jól olvasható.

61 Nbk 60. 
ebben az esetben a táblát nem Addaru hónapban, hanem Ulūlu hónapban (VI. hónap) írták, ${ }^{62}$ és a $20 \%$ kamatot nem Ulūlu hónap valamelyik napjától számították, mint ahogyan az megfigyelhető volt az előző két esetben, hanem Tašrītu hónaptól (VII. hónap) kezdve. ${ }^{63}$

Azonban Tašrìtu nem a következő hónap volt abban az évben, hanem a második a szerződéskötés hónapjához képest, mivel II. Nabû-kudurrī-uṣur 7. évében beiktattak egy Ulūlu szökőhónapot. Ismételten látható tehát, hogy a szökőhónapban való kamat(rész) fizetésének, felszámításának elkerülése volt az oka annak, hogy a kölcsönt a korábbiaktól eltérve miért Ulūlu hónapban újították meg. A normál Ulūlu idejére vonatkozó kamat érvényes volt az előző megállapodás értelmében, az új egyezség pedig arra mutat rá, hogy a feltételek, a kölcsön alapvető jellemzői változatlanok maradnak, de mivel az új szerződés feltételei szerint a kamat fizetésének a kezdete Tašrītu hónapra esik, ezért a szerződés hónapja és Tašrītu közötti Ulūlu szökőhónapban nem kellett kamatot fizetni. Miközben a kölcsönt a szökőhónap beiktatásának apropóján megújították, a szerződő felekben való változást is realizálták, ahogy a szöveg első kiadója Funck vélte. ${ }^{64}$

A szökőhónap elötti, normál Ulūlu hónapban való megújítás alátámaszthatja Földi Zsombor, óbabilóni (Kr. e. 20-16. század) házbérleti szerződések beköltözési és kiköltözési záradékai vizsgálatán nyugvó javaslatát, mely szerint az új szökőhónap beiktatásáról legalábbis néhány esetben, a szökőhónapot megelőző hónapban már elöre tudhattak a babilóniaiak. ${ }^{65}$

Összességében elmondható, hogy a fentebb leírtak rávilágítanak arra, hogy a szökőhónapokat hogyan kezelték kamatozó kölcsönszerzödések esetében az újbabilóni és későbabilóni korban. Szökőévek során az adósoknak tizenhárom hónapra kellett fizetniük kamatot, amit nem az éves kamatláb havi 1/12 arányszámának újraszámolásával értek el havi 1/13-okra átszámolva, ${ }^{66}$ akár visszamenőlegesen is, hanem az adott évben 13/12 hónapnyi kamatot fizetve, tehát egy hónapnyi kamattal többet, mint normál évek esetében. Ezt a megállapítást támasztják alá a szökőhónapokban kötött szerzödések, amelyek többségében nem találunk semmilyen olyan különleges záradékot, vagy kitételt, ami a szökőhónapoknak a szokásostól eltérő kezelését mutatná. Ezt az álláspontot támasztja alá a BM 31230 és valószínűleg az Nbk 60 forrás is. Mindkettő lejegyzésének a motivációja annak a plusz egyhavi kamatnak

62 Nbk 60: 13-14. sorok.

63 Nbk 60: 3-5. sorok.

64 Ahogyan Funck (1982. 52.) feltételezte.

65 Lásd Földi 2009b. 19 és 22. Az újbabilóni kor házbérleti szerződéseiben az itt megnevezett óbabilóni kitételekhez hasonló záradék nem ismert, lásd legújabban Zawadzki 2018. különösen 57-58. A mezopotámiai házbérletekről magyarul lásd Földi 2009a. (óbabilóni kor) és Csabai 2003. (újbabilóni kor).

$66 \mathrm{Ez}$ a módja a kamat újraszámolásának valóban követhetetlenné tette volna a kamat fizetését. 
a fizetésének az elkerülése volt, amit a szökőhónap beiktatása miatt kellett volna kifizetni. A fenti esetekben megfigyelhetö extra kamat felszámításának elkerülésére tett törekvések mutatják meg számunkra, hogy a szökőévek szökőhónapjainak idejére is ugyanúgy egyhavi kamatot kellett fizetni.

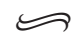

\section{Melléklet}

Nbk 34. (=Liv 5.)

ezüst kötelezvény

Šahrītu, II. Nabû-kudurrī-uṣur 3-XII-15 (Kr. e. 601. március)

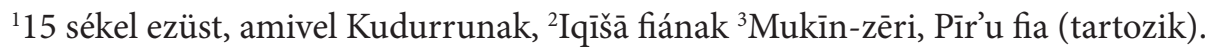

Addaru hónap 20. napjától ${ }^{4}$ havonta minánként ${ }^{5} 1$ sékel ezüsttel növekszik ${ }^{6}$ a terhére.

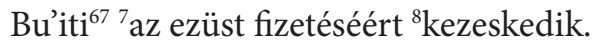

${ }^{9}$ Tanúk: Sîn-kēšir, ${ }^{10}$ Sinn-ah-iddin fia, Iddin-ahi, ${ }^{11}$ Nabû-êtị fia, és az

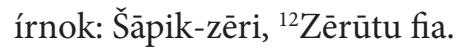

Šahrītu, ${ }^{13-15}$ Addaru hónap 15. Nabû-kudurrī-uṣur, Babilón királyának 3. éve.

\section{Nbk 39}

ezüst kötelezvény

Šahrītu, II. Nabû-kudurrī-uṣur 4-XII-[...] (Kr. e. 600. február-március)

${ }^{1} 15$ sékel ezüst, amivel Kudurrunak, ${ }^{2}$ Iqīiša fiának Kīnā ${ }^{68},{ }^{3} \mathrm{P} i \bar{r}$ 'u fia és Bư iti, a felesége (tartozik).

${ }^{4}$ Addaru hónap [... napjától] havonta minánként ${ }^{5} 1$ sékel ezüsttel növekszik a terhére.

${ }^{6}$ Egyik kezeskedik a másikért.

${ }^{7}[\ldots]$ ráadást Addaruban

${ }^{8}[$ Kudurrunak fiz]et.

Tanúk: ${ }^{9}[\ldots],[\ldots]$ fia, [és az

írnok: ..., $\left.{ }^{10} \ldots\right]$ fia.

Šahrītu, Addaru hónap ${ }^{11}[\ldots]$. Nabû-kudurrī-ușur, ${ }^{12}$ Babilón királyának 4. éve.

68 Mukīn-zēri rövidített neve. 
Nbk 60 (=Liv 141)

ezüst kötelezvény

Šahrītu, II. Nabû-kudurrī-uṣur 7-VI-22 (Kr. e. 598. szeptember)

${ }^{1} 15$ sékel ezüst, amivel Kudurrunak, Iqīšā fiának ${ }^{2}$ Bu’iti, ${ }^{3}$ Mukīn-zēri felesége (tartozik).

${ }^{4}$ Havonta minánként 1 sékel ezüsttel ${ }^{5}$ növekszik a terhére.

Az ezüstöt ${ }^{6} \mathrm{Nabû}-$ nāṣirnak kell adnia.

${ }^{7}$ Előző adóslevelet összetörték.

${ }^{8}$ Tanúk: Zērīya, ${ }^{9}[. .$.$] fia, Marduk-zēr-ibni, { }^{10}[$.. fia, Šulā, $]$ Zēru-ukīn fia,

${ }^{11}$ [Kudurru,] Iqī̌sā fia,

${ }^{12}$ és az írnok Zēriya, Šuma-ușur fia

${ }^{13}$ Šahrītu, Ulūlu hónap 22.

14-15Nabû-kudurrī-ușur, Babilón királyának 7. éve.

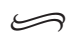

\section{Források}

BE 8/1 = Clay, Albert T.: Legal and Commercial Transactions, Dated in the Assyrian, Neo-Babylonian and Persian Periods, Chiefly from Nippur. Philadelphia, 1908. (The Babylonian Expedition of the University of Pennsylvania 8/1.)

Bertin $=$ Unpublished autographs in the British Museum, London.

Cyr = Strassmaier, Johann N.: Inschriften von Cyrus, König von Babylon (538-529 v. Chr.). Leipzig, 1890. (Babylonische Texte 7.)

Dar $=$ Strassmaier, Johann N.: Inschriften von Darius, König von Babylon (521-486 v. Chr.). Leipzig, 1897. (Babylonische Texte 10-12.)

Joannès 2000/2002 = Joannès, Francis: Strassmaier, Darius 170. (http://www.achemenet.com/fr/item/?/sources-textuelles/textes-par-langues-et-ecritures/babylonien/archives-egibi/1655924 - Letöltés: 2019. október 17.).

Liv = Strassmaier, Johann N.: Die babylonischen Inschriften im Museum zu Liverpool nebst andern aus der Zeit von Nebukadnezzar bis Darius. Leiden, 1885.

Nbk = Strassmaier, Johann N.: Inschriften von Nabochodonosor, König von Babylon 604-561 v. Chr. Leipzig, 1889. (Babylonische Texte 5-6.)

Nbn = Strassmaier, Johann N.: Inschriften von Nabonidus, König von Babylon 555538 v. Chr. Leipzig, 1889. (Babylonische Texte 1-4.)

OECT 12 = Joannès, Francis: Les tablettes néo-babyloniennes de la Bodleian Library conservées à l'Ashmolean Museum. Oxford, 1990. (Neo-Babylonian Tablets in the Asmolean Museum). (Oxford Editions of Cuneiform Texts 12.) 
TCL 12 = Contenau, Georges: Contrats néo-babyloniens I. de Téglath-phalasar III à Nabonide. Paris, 1927. (Textes Cunéiformes, Musée du Louvre 12.)

TMH $2 / 3$ = Krückmann, Oluf: Neubabylonische Rechts- und Verwaltungstexte. (Texte und Materialien der Frau Professor Hilprecht Collection of Babylonian Antiquities im Eigentum der Universität Jena 2/3) Leipzig, 1933.

VS 3 = Ungnad, Arthur: Vorderasiatische Schriftdenkmäler der königlichen Museen zu Berlin. Heft 3. Leipzig, 1907.

VS 4 = Ungnad, Arthur: Vorderasiatische Schriftdenkmäler der königlichen Museen zu Berlin. Heft 4. Leipzig, 1907.

YOS 19 = Beaulieu, Paul-Alain: Legal and Administrative Texts from the Reign of Nabonidus. New Haven - London, 2000. (Yale Oriental Studies, Babylonian Texts 19.)

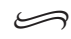

\section{Felhasznált irodalom}

Abraham 2004 = Abraham, Kathleen: Business and Politics under the Persian Empire. The Financial Dealings of Marduk-nāșir-apli of the House of Egibi (521-487 B.C.E.). Bethesda, 2004.

$\mathrm{BM}=$ Museum siglum, British Museum, London.

Britton 2002 = Britton, John P.: Predictions of Lunar Phenomena in Babylonian Astronomy. In: Steele, John M. - Imhausen, Annette (ed.): Under One Sky: Astronomy and Mathematics in the Ancient Near East. Münster, 2002. 5-20. (Alter Orient und Altes Testament 297.)

Corfù $2010=$ Corfù, Nicolas A.: Die sogenannten achaimenidischen Bogenschützenmünzen - Die Herkunft von Dareikoi und Sigloi. Archäologische Mitteilungen aus Iran und Turan 42. (2010), 165-206.

Csabai 2003 = Csabai Zoltán: Egy babiloni magánarchívum házbérleti szerződései. Sic Itur Ad Astra 2-3. (2003), 75-108.

Csabai 2006 = Csabai Zoltán: Babilónia gazdaságtörténete a kölcsönszerződések tükrében (Kr.e. 1. évezred). Ókor V/3-4. (2006), 84-90.

Csabai 2008 = Csabai Zoltán: Verbrauchsdarlehen in Babylonien im 1. Jtsd. v. Chr. Eine Vorstudie. In: Vargyas, Péter - Szabó, Ádám (ed.): Cultus Deorum Studia Religionum ad Historiam. Vol. I. De Oriente Antiquo et Regione Danuvii Praehistorica in Memoriam István Tóth. Pécs, 2008. 203-218. (Ókortudományi Dolgozatok 1.)

Csabai 2015 = Csabai Zoltán: Kamatmentes és ál-kamatmentes kölcsönök Babilóniában. In: Csabai Zoltán - Földi Zsombor - Grüll Tibor - Vér Ádám (szerk.): 
Ökonómia és ökológia. Tanulmányok az ókori gazdaságtörténet és történeti földrajz köréböl. Pécs-Budapest, 2015. 141-152. (Ókor-Történet-Írás 3.)

Csabai 2018a = Csabai, Zoltán: Antedated Paying of Interest in the Neo-Babylonian and Achaemenid Periods. In: Grüll, Tibor (ed.): Mobility and Transfer. Studies on Ancient Economy. Pécs - Budapest, 2018. 17-34. (Ancient Near Eastern and Mediterranean Studies 3.)

Csabai 2018b = Csabai Zoltán: Hitel és kamat az Újasszír Birodalomban az i. e. 8-7. században. In: Vitári Zsolt (szerk.): Globális vetületek: Ünnepi kötet Fischer Ferenc 65. születésnapjára. Budapest-Pécs, 2018. 17-33.

Cseke 2008 = Cseke Henrietta: Századokon innen. Az ókori időszámítások problémái. Világtörténet 30. (2008) 3-11.

Cseke 2014 = Cseke, Henrietta: The Economic Determination of the Changing Interests. A Survey Based on the Loan Documents of the Neo-Babylonian Sîn-uballit Archive. In: Csabai, Zoltán (Ed.): Studies in Economic and Social History of the Ancient Near East in Memory of Péter Vargyas. Pécs-Budapest, 2014. 557-578. (Ancient Near Eastern and Mediterranean Studies 2.)

Dillard 1975 = Dillard, Raymond B.: Neo-Babylonian Texts from the John Frederick Lewis Collection of the Free Library of Philadelphia. Diss., Dropsie University, 1975. Manuscript.

Ellis 1984 = Ellis, Maria deJong: Neo-Babylonian Texts in the Yale Babylonian Collection. Journal of Cuneiform Studies 36. (1984), 1-63.

Földi 2009a = Földi Zsombor J.: A házbérlet és szerepe az óbabilóni korban. In: Rab Virág - Schwarzwölder Ádám - Varga Mónika (szerk.): 7. Országos Interdiszciplináris Grastyán Konferencia előadásai. Pécs, 2009. 79-87.

Földi 2009b = Földi, Zsombor J.: Rïbatum. The Archive of a Priestess from Old Babylonian Sippar / Rỉbatum. Egy papnő archívuma az óbabilóni Szipparból. BA-thesis, ELTE Budapest, 2009. Manuscript.

Funck 1982 = Funck, Bernd: Studien zur sozialökonomischen Situation Babyloniens im 7. und 6. Jahrhundert v. u. Z. In: Klengel, Horst (Hrsg.): Gesellschaft und Kultur im alten Vorderasien. Berlin, 1982. 47-67. (Schriften zur Geschichte und Kultur des Alten Orients 15.)

Hahn 1988 = Hahn István: Naptári rendszerek és időszámítás. Budapest, 1988.

Hunger $1970=$ Hunger, Hermann: Das Archiv des Nabû-ušallim. Baghdader Mitteilungen 5. (1970), 193-204.

Hunger 1977 = Hunger, Hermann: Kalender. In: Edzard, Dietz O. (Hrsg.): Reallexikon der Assyriologie und Vorderasiatischen Archäologie, Band 5. Berlin - New York, 1977. 297-303.

Hunger - Pingree 1999 = Hunger, Hermann - Pingree, David: Astral Sciences in Mesopotamia. Leiden - Boston - Köln, 1999. (Handbuch der Orientalistik I, 44.) 
Jursa 1998 = Jursa, Michael: Der Tempelzehnt in Babylonien vom siebenten bis zum dritten Jahrhundert v. Chr. Münster, 1998. (Alter Orient und Altes Testament 254.)

Jursa 2002 = Jursa, Michael: Debt and Indebtedness in the Neo-Babylonian Period: Evidence from the Institutional Archives. In: Hudson, Michael - Van De Mieroop, Marc (ed.): Debt and Economic Renewal in the Ancient Near East. Bethesda, 2002. 197-219. (The International Scholars Conference on Ancient Near Eastern Economies 3.)

Jursa et al. $2010=$ Jursa, Michael et al.: Aspects of the Economic History of Babylonia in the First Millennium B.C. Economic Geography, Economic Mentalities, Agriculture, the Use of Money and the Problem of Economic Growth. Münster, 2010. (Alter Orient und Altes Testament 377., Veröffentlichungen zur Wirtschaftsgeschichte Babyloniens im 1. Jahrtausend v. Chr. 4.)

Jursa 2015 = Jursa, Michael: Labor in Babylonia in the First Millennium BC. In: Steinkeller, Piotr - Hudson, Michael (ed.): Labor in the Ancient World. Dresden, 2015. 345-396. (The International Scholars Conference on Ancient Near Eastern Economies 5.)

Kessler 1991 = Kessler, Karlheinz: Uruk. Urkunden aus Privathäusern. Die Wohnhäuser westlich des Eanna-Tempelbereichs, Teil I. Die Archive der Söhne des Bēl-ušallim, des Nabû-ušallim und des Bēl-supê-muhur. Mainz am Rhein, 1991. (Ausgrabungen in Uruk-Warka, Endberichte 8.)

Kleber 2008 = Kleber, Kristin: Tempel und Palast. Die Beziehungen zwischen dem König und dem Eanna-Tempel im spätbabylonischen Uruk. Münster, 2008. (Alter Orient und Altes Testament 358.)

Oelsner 2001 = Oelsner, Joachim: Neo-Babylonian Period. In: Westbrook, Raymond Jasnow, Richard (ed.): Security for Debt in Ancient Near Eastern Law. LeidenBoston-Köln, 2001. 289-305. (Culture and History of the Ancient Near East 9.) Oelsner - Wells - Wunsch 2003 = Oelsner, Joachim - Wells, Bruce - Wunsch, Cornelia: Neo-Babylonian Period. In: Westbrook 2003. 911-974.

Ossendrijver 2018 = Ossendrijver, Mathieu: Babylonian Scholarship and the Calendar during the Reign of Xerxes. In: Waerzeggers, Caroline - Seire, Maarja (ed.): Xerxes and Babylonia. The Cuneiform Evidence. Leuven, 2018. 135-163. (Orientalia Lovaniensia Analecta 277.)

Petschow 1956 = Petschow, Herbert: Neubabylonisches Pfandrecht. Berlin, 1956.

Pirngruber 2016 = Pirngruber, Reinhard: The Value of Silver: Wages as Guides to the Standard of Living in First Millennium BC Babylonia. In: Kleber, Kristin - Pirngruber, Reinhard (ed.): Silver, Money and Credit. A Tribute to Robertus J. van der Spek on the Occasion of His $65^{\text {th }}$ Birthday. Leiden, 2016. 107-118. (Publications de l'Institut historique et archéologique néerlandais de Stamboul 128.) 
Powell 1999 = Powell, Marvin A.: Wir müssen unsere Nische nützen: Monies, Motives, and Methods in Babylonian Economics. In: Dercksen, Jan G. (ed.): Trade and Finance in Ancient Mesopotamia. Leiden, 1999. 5-24. (MOS Studies 2., Publications de l'Institut historique et archéologique néerlandais de Stamboul 84.)

Ratzon 2016 = Ratzon, Eshbal: Early Mesopotamian Intercalation Schemes and the Sidereal Month. Mediterranean Archaeology and Archaeometry 16. (2016), 143-151.

San Nicolò 1933 = San Nicolò, Mariano: Parerga Babyloniaca X-XI. Archiv Orientální 5. (1933), 284-302.

Shiff 1988 = Shiff, Laurence B.: Neo-Babylonian "Interest-Free" Promissory Notes. Journal of Cuneiform Studies 40. (1988), 187-194.

Skaist 1994 = Skaist, Aaron: The Old Babylonian Loan Contract. Its History and Geography. Ramat Gan, 1994.

Slanski 2003 = Slanski, Kathryn: Middle Babylonian Period. In: Westbrook 2003a. 485-520.

Steele 2007 = Steele, John M.: The Length of the Month in Mesopotamian Calendars of the First Millennium B.C. In: Steele, John M. (ed.): Calendars and Years: Astronomy and Time in the Ancient Near East. Oxford, 2007. 133-148.

Steele 2011 = Steele, John M.: Making Sense of Time: Observational and Theoretical Calendars. In: Radner, Karen - Robson, Eleanor (ed.): The Oxford Handbook of Cuneiform Culture. Oxford, 2011. 470-485.

Stratford 2015 = Stratford, Edward: Successor Eponyms, Debt Notes, Intercalation, and the Old Assyrian Calendar during Kültepe Level II: A Critical Reappraisal. Journal of Near Eastern Studies 74. (2015), 301-324.

Van De Mieroop 1995 = Van De Mieroop, Marc: Old Babylonian interest rates: Were they annual? In: Van Lerberghe, Karel - Schoors, Antoon (ed.): Immigration und Emigration within the Ancient Near East. Festschrift E. Lipiński. Leuven, 1995. 357-364. (Orientalia Lovaniensia Analecta 65.)

Van De Mieroop 2005 = Van De Mieroop, Marc: The Invention of Interest: Sumerian Loans. In: Goetzmann, William N. - Rouwenhorst, K. Geert (ed.): The Origins of Value. The Financial Innovations that Created Modern Capital Markets. Oxford, 2005. 17-30., 359-361.

Vargyas 1999 = Vargyas, Péter: Kaspu ginnu and the Monetary Reform of Darius

I. Zeitschrift für Assyriologie und vorderasiatische Archäologie 89. (1999), 247-268.

Vargyas 2000 = Vargyas, Péter: Babylonian Interest Rates: Weren’t They Annual? In: Graziani, Simonetta (ed.): Studi sul Vicino Oriente antico dedicati alla memoria di Luigi Cagni. Napoli, 2000. 1095-1105. (Istituto Universitario Orientale, Dipartimento di Studi Asiatici, Series Minor 61.) 
Vargyas 2001 = Vargyas, Péter: A History of Babylonian Prices in the First Millennium

B.C. Vol. I. Prices of the Basic Products. Heidelberg, 2001. (Heidelberger Studien zum Alten Orient 10.)

Vargyas 2010 = Vargyas, Péter: A pénz története Babilóniában a pénzverés előtt és után. Pécs - Budapest, 2010. (Ókor-Történet-Írás 1.)

Westbrook 2003a = Westbrook, Raymond (ed.): A History of Ancient Near Eastern Law Leiden - Boston, 2003. (Handbuch der Orientalistik I. 72/1-2.)

Westbrook 2003b $=$ Westbrook, Raymond: Old Babylonian Period. In: Westbrook 2003. 361-430.

Wunsch 1999a = Wunsch, Cornelia: Handel und Wandel in Babylon: Die Geschäfte der Familie Egibi. In: Seipel, Wilfried et al. (Hrsg.): Von Babylon bis Jerusalem. Die Welt der orientalischen Königsstädte II. Milano, 1999. 325-333.

Wunsch 1999b = Wunsch, Cornelia: Neubabylonische Urkunden: Die Geschäftsurkunden der Familie Egibi. In: Renger, Johannes (Hrsg.): Babylon: Focus mesopotamischer Geschichte, Wiege früher Gelehrsamkeit, Mythos in der Moderne. Saarbrücken, 1999. 343-364. (Colloquien der Deutschen Orientgesellschaft 2.)

Wunsch 2000 = Wunsch, Cornelia: Das Egibi-Archiv. I. Die Felder und Gärten. Groningen, 2000. (Cuneiform Monographs 20 A-B.)

Wunsch 2002 = Wunsch, Cornelia: Debt, Interest, Pledge and Forfeiture in the Neo-Babylonian and Early Achaemenid Period: The Evidence from Private Archives. In: Hudson, Michael - Van De Mieroop, Marc (ed.): Debt and Economic Renewal in the Ancient Near East. Bethesda, 2002. 221-255. (The International Scholars Conference on Ancient Near Eastern Economies 3.)

Wunsch 2007 = Wunsch, Cornelia: The Egibi family. In: Leick, Gwendolyn (ed.): The Babylonian World. London - New York, 2007. 236-247.

Zawadzki 2018 = Zawadzki, Stefan: The Rental of Houses in the Neo-Babylonian Period (VI-V. Centuries BC). Warsaw, 2018. 